\title{
Rancang Bangun Alat Monitoring Suhu Tubuh Untuk Pasien Demam Berdarah Menggunakan Smartphone Berbasis Internet Of Things
}

\author{
Fahri Satriya ${ }^{1}$, Mardiono $^{2}$, Reza Diharja ${ }^{* 3}$ \\ 1,2,3 Jurusan Teknik Elektro, Universitas Jayabaya \\ raharjofahri@gmail.com ${ }^{1}$, mardiono@ftijayabaya.ac.id², reza.diharja@jayabaya.ac.id ${ }^{3}$
}

\begin{abstract}
Abstrak
Penyakit demam berdarah mudah menular. Media penularan pada penyakit demam berdarah sendiri disebabkan gigitan nyamuk Aedes aegypti dan Aedes albocpictus. Tiga tahap pada penyakit demam berdarah yaitu demam, kritis, dan pemulihan. Pada fase demam yaitu seseorang biasanya mengalami demam yang tinggi. Demam mencapai 40 derajat celsius. Untuk mengetahui kondisi suhu tubuh pasien penyakit demam berdarah, diperlukan alat monitoring suhu tubuh. Monitoring tersebut bisa di lihat dimana pun dengan memanfaatkan Internet of Things untuk mengetahui keadaan suhu tubuh pasiennya. Alat yang dibuat akan memanfaatkan sensor suhu DS18B20 untuk mendeteksi suhu tubuh pasien, nilai suhu tubuh tersebut sebagai input yang data nya akan diolah oleh mikrokontroler WeMos. Setelah itu data akan dikirim ke firebase sebagai cloud menggunakan jaringan internet. Output dari sistem ini akan ditampilkan di smartphone dalam bentuk aplikasi android. Aplikasi smartphone dibuat menggunakan platform AppInventor dan menampilkan Nama, Umur, Kamar, Tanggal Masuk dan Suhu Tubuh pasien satu dan pasien dua serta dilengkapi peringatan kode warna, kuning, hijau, merah pada tampilan digital. Kesimpulan dari rancangan sistem ini didesain dapat memudahkan perawat atau dokter memonitoring kondisi suhu tubuh pasien demam berdarah dan pasien penyakit lainnya melalui aplikasi smartphone secara realtime dari jarak jauh tanpa mendatangi tempat pasien dan terdapat data rekam medik untuk melihat hasil monitoring di smartphone. Tingkat akurasi pengukuran suhu ketika di implementasikan pada orang dewasa yaitu $99,45 \%$.
\end{abstract}

Kata Kunci : Firebase, Internet Of Things, WeMos D1 Mini, Sensor Suhu, Smartphone

\begin{abstract}
Dengue fever is a contagious disease. The means of transmitting dengue fever comes from the bites of Aedes aegypti and Aedes albocpictus mosquitoes. Dengue fever occurs in three stages: Fever, critical, and recovery. In the febrile phase, a person usually has a high fever. Body heat often reaches 40 degrees Celsius. To find out the condition of the body temperature of a patient with dengue fever, a body temperature monitoring tool is needed. This monitoring can be seen anywhere by using the Internet of Things to find out the state of the patient's body temperature. The tool made will use the DS 18B20 temperature sensor to detect the patient's body temperature, the body temperature value as an input whose data will be processed by the WeMos microcontroller. After that the data will be sent to Firebase as a cloud using the internet network. The output from this system will be displayed on the smartphone in the form of an android application. The smartphone application is made using the AppInventor platform and displays the Name, Age, Room, Entry Date and Body Temperature of patient one and patient two and is equipped with color coded warnings, yellow, green, red on the digital display. The conclusion from the design of this system is designed to make it easier for nurses or doctors to monitor the condition of the body temperature of dengue fever patients and other disease patients through a smartphone application in real time remotely without visiting the patient's place and there is medical record data to see the monitoring results on a smartphone.
\end{abstract}

Keywords : Firebase, Internet Of Things, WeMos D1 Mini, Smartphone,Temperature Sensor

\section{PENDAHULUAN}

Seiring dengan perkembangan teknologi, peralatan kesehatan telah dirancang agar dapat mengikuti perkembangan teknologi tersebut. Hal ini bertujuan untuk meningkatkan pelayanan kesehatan kepada masyarakat khususnya di rumah sakit. Dengan adanya perkembangan ini maka diharapkan dapat memberikan kemudahan bagi tenaga kesehatan dalam mendiagnosa maupun melakukan terapi terhadap suatu penyakit.Penyakit Demam Berdarah Dengue (DBD) adalah penyakit demam akut yang disebabkan oleh infeksi virus dengue yang masuk dan bersiklus di dalam tubuh nyamuk yaitu melalui gigitan nyamuk Aedes aegypty dan Aedes albopictus berkelamin betina, virus Dengue tersebut ditularkan 
keperedaran darah manusia. Penyakit ini dapat berakibat fatal yaitu kematian pada penderitanya[1].

Gejala penyakit ini yakni mendadak demam tinggi selama 2-7 hari dengan suhu badan antara $38{ }^{\circ} \mathrm{C}$ sampai $40^{\circ} \mathrm{C}$ atau lebih. Monitoring suhu tubuh penderita setiap saat sangat diperlukan untuk mengetahui kondisi tubuh penderita terhadap fasefase infeksi virus sehingga penanganan penyakit tersebut dapat teratasi secara efektif oleh perawat atau dokter. Oleh sebab itu diperlukan suatu metode yang dapat membantu perawat atau dokter dalam memonitoring perkembangan kesehatan pasien, salah satunya dengan memantau suhu tubuh.

Di era digital banyak hal yang kita jumpai berbasis Internet of Things (IoT). IoT adalah sebuah konsep dimana sebuah benda di dunia nyata yang terintegrasi kedalam sebuah sistem terpadu yang saling berkomunikasi dengan sistem lain melalui jaringan internet[2][3]. Dimana hal ini dapat memudahkan tenaga medis khususnya perawat atau dokter dalam memonitoring kondisi suhu tubuh pasien.

Pembuatan sistem pengukur suhu tubuh menggunakan sensor DS18B20 yang berfungsi mengambil data suhu tubuh pengguna. Modul WeMos ESP8266 berfungsi sebagai pusat kendali dan device untuk terhubung ke jaringan internet. Smartphone digunakan untuk memantau keadaan suhu pengguna.

\section{METODOLOGI}

\subsection{Perancangan Sistem Monitoring Suhu Tubuh Untuk Pasien Demam Berdarah}

Alat ini dibuat dengan fungsi memonitor kondisi suhu tubuh pasien demam berdarah menggunakan smartphone berbasis internet of things yang dibuat untuk dua pasien sekaligus dengan menampilkan Nama, Umur, Kamar, Tanggal Masuk dan Suhu Tubuhnya secara terus menerus dan memberikan peringatan kode warna kuning jika suhu $\left(30,0^{\circ} \mathrm{C}-\right.$ $\left.35,9^{\circ} \mathrm{C}\right)$ suhu Hipotermia, warna hijau $\left(36^{\circ} \mathrm{C}-37,9^{\circ} \mathrm{C}\right)$ suhu normal dan warna merah $\left(38^{\circ} \mathrm{C}-43^{\circ} \mathrm{C}\right)$, suhu demam atau panas tinggi, serta diberikan alarm jika suhu pasien tersebut dibawah maupun diatas suhu tubuh normal, sehingga suhu pasien dapat di monitor dengan baik serta mempermudah perawat atau dokter untuk memonitor suhu pasien dari jarak jauh. Cara kerja alat ini adalah ketika alat di ON maka akan muncul tulisan alat monitoring suhu tubuh untuk pasien demam berdarah. Kemudian program mikrokontroler wemos juga mencari koneksi Internet agar dapat terhubung dengan koneksi internet/ wifi yang tersedia dan yang sudah atur, apabila wifi tidak ditemukan maka LCD akan menampilkan Not
Connected dan apabila ditemukan, maka LCD akan menampilkan connected. Sensor suhu DS18B20 yang diletakkan di ketiak pasien akan mendeteksi suhunya data tersebut dikirimkan ke mikrokontroler WeMos untuk diolah selanjutnya ditampilkan pada LCD dan dikirim ke cloud server firebase. Android akan di instalkan sebuah aplikasi yang sudah di program. Aplikasi tersebut dirancang menggunakan software Appinventor. Sehingga dapat digunakan untuk menarik data yang terdapat pada clouds server firebase dan menampilkannya pada layar smartphone.

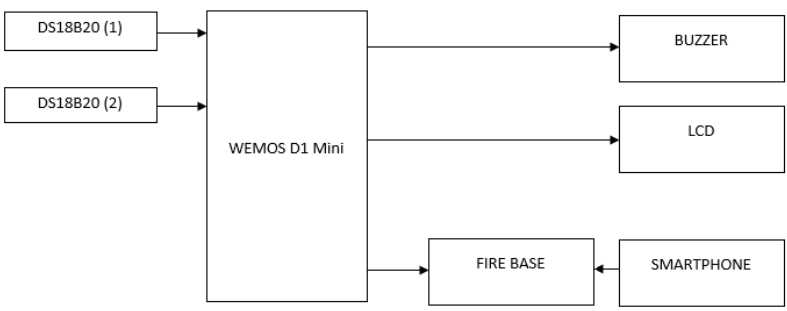

Gambar 1 Diagram alir sistem monitoring suhu tubuh untuk pasien demam berdarah

\subsection{Sensor Suhu DS18B20}

Sensor DS18B20 merupakan salah satu sensor suhu digital yang diproduksi oleh Dallas Semiconductor. Pembacaan suhu pada sensor DS18B20 menggunakan protokol satu wire communication. DS18B20 memiliki 3 pin yang terdiri dari pin $+5 \mathrm{~V}$, ground dan data input/output. Sensor DS18B20 merupakan sensor suhu 9-12 bit yang berfungsi seperti termometer[4]. Sensor DS18B20 memiliki kemampuan untuk mengukur suhu pada kisaran $-55^{\circ} \mathrm{C}$ sampai $125^{\circ} \mathrm{C}$. Selain itu, daya yang digunakan sensor suhu DS18B20 bisa langsung didapat dari data line, sehingga tidak perlu lagi listrik eksternal. Sensor DS18B20 memiliki keunikan yaitu 64-bit, yang memungkinkan DS18B20 terhubung ke beberapa fungsi yang sama melalui satu kabel yang sama.

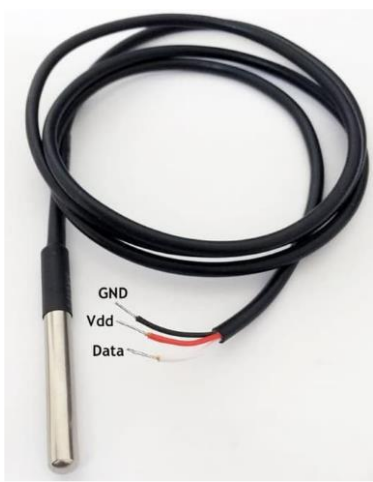

Gambar 2 Sensor DS18B20 


\subsection{WeMos D1 Mini ESP8266}

Mikrokontroler ini berbasis ESP8266 yaitu sebuah modul mikrokontroler nirkabel (Wifi) 802.11 yang kompatibel dengan Arduino IDE. Tata letak mikrokontroler tersebut didasarkan pada desain hardware arduino standar dengan proporsi yang sama dengan Arduino Uno dan Leonardo. Mikrokontroler tersebut juga sudah termasuk satu set header Arduino standar yang artinya kompatibel dengan beragam Arduino shield. Mikrokontroler ini juga mencakup sebuah CH340 USB to serial interface seperti kabel USB micro yang umum digunakan[5].

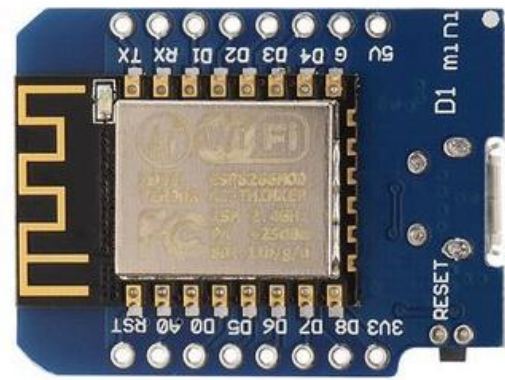

\section{Gambar 3 WeMos D1 Mini ESP8266}

\subsection{Aplikasi Desain AppInventor}

AppInventor menggunakan antarmuka grafis, serupa dengan antarmuka pengguna pada scratch dan star logo $T N G$, yang memungkinkan pengguna untuk mengambil dan manaruh objek visual untuk menciptakan aplikasi yang bisa dijalankan pada perangkat Android. Dalam menciptakan AppInventor, Google telah melakukan riset yang berhubungan dengan komputasi edukasional dan menyelesaikan lingkungan pengembangan online Google[6]. Pada AppInventor ini terdapat beberapa komponen yang terdiri dari:

1) Komponen desainer yang berjalan pada browser digunakan untuk memilih komponen yang diperlukan untuk mengatur propertynya. Pada komponen desainer sendiri terdapat 5 bagian, yaitu palette, viewer, component, media dan properties.

2) Block Editor berjalan di luar browser dan digunakan untuk membuat serta mengatur behaviour dari komponen-komponen yang akan kita pilih dari komponen desainer.

3) Emulator yang digunakan untuk menjalankan dan menguji project yang telah dibuat.

\subsection{Internet of Things}

Internet of Things atau dikenal juga dengan singkatan "IoT" merupakan sebuah konsep yang bertujuan untuk memperluas manfaat dari konektivitas internet yang tersambung secara terusmenerus. Adapun kemampuan seperti berbagi data, remote control dan sebagainya termasuk pada semua benda fisik didunia[7]-[9]. Contohnya peralatan apa saja, termasuk benda hidup yang semuanya tersambung ke jaringan lokal dan global melalui sensor yang tertanam dan selalu aktif. Ide awal internet of things ini pertama kali dimunculkan oleh Kevin Ashton pada tahun 1999 dan mulai terkenal dengan Auto-ID Center di Institut Teknologi Massachusetts (MIT). Internet of things ini diprediski sebagai "the next big thing" di dunia teknologi informasi. Hal tersebut dikarenakan konsep ini menawarkan banyak potensi yang bisa dikembangkan. Barang apapun dapat dikatakan sebagai internet of things device jika telah terpasang IoT modulelembeded device, IoT Module pada umumnya terdiri dari 5 komponen penting diantaranya sensor, komputer, sistem operasi, jalur komunikasi dan keluaran[10].

\section{HASIL DAN PEMBAHASAN}

\subsection{Hasil Perancangan}

Hasil tampilan keseluruhan dari perancangan alat monitoring suhu tubuh untuk pasien demam berdarah menggunakan smartphone berbasis internet of things dapat ditunjukkan pada Gambar 4.

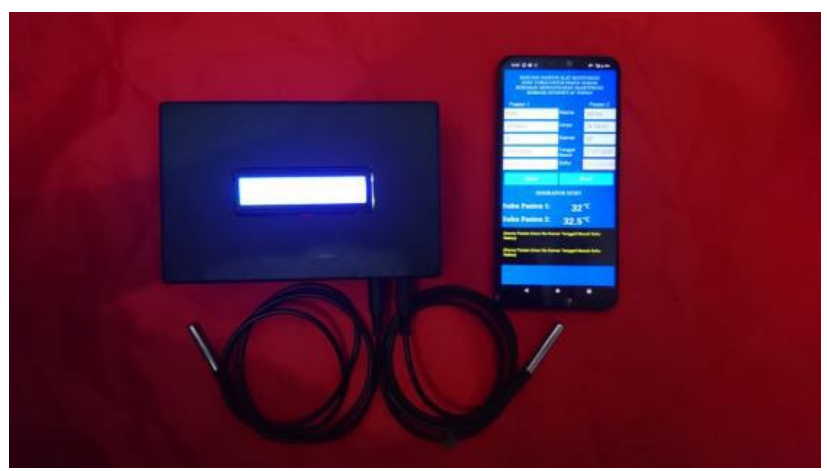

Gambar 4 Sistem monitoring suhu tubuh untuk pasien demam berdarah menggunakan smartphone

\subsection{Pengujian Alat}

Pengujian alat dilakukan untuk mengetahui alat yang dirancang apakah sudah berfungsi dengan baik. Pengujian dilakukan dengan mengambil data pada sensor suhu, peringatan kode warna suhu dan buzzer. Diperlukan alat penguji sebagai pembanding nilai hasil dari alat, berikut alat penguji yang digunakan :

1) Alat kalibrasi suhu waterbath

2) Thermometer 


\subsection{Pengujian Sensor Suhu}

Pengujian kalibrasi pada sensor suhu menggunakan waterbath. Waterbath merupakan suatu alat yang digunakan untuk kalibrasi suhu termometer (pengukur suhu tubuh). Waterbath merupakan peralatan laboratorium metrologi suhu yang terbuat dari wadah yang diisi dengan air. Alat ini dilengkapi dengan pemanas (heater) untuk memanaskan air hingga suhu $100{ }^{\circ} \mathrm{C}$, dan sensor suhu untuk mendeteksi suhu air.

Tabel 1 hasil pembacaan sensor suhu satu dan alat kalibrasi suhu

\begin{tabular}{|l|l|l|l|}
\hline No & Thermometer $\left({ }^{\circ} \mathrm{C}\right)$ & $\begin{array}{l}\text { Sensor } \\
\text { Suhu }\left({ }^{\circ} \mathrm{C}\right)\end{array}$ & Error $(\%)$ \\
\hline 1 & 30,6 & 30,75 & 0,46 \\
\hline 2 & 35,2 & 35,0 & 0,57 \\
\hline 3 & 36,0 & 36,0 & 0 \\
\hline 4 & 37,3 & 37,5 & 0,54 \\
\hline 5 & 38 & 38,25 & 0,66 \\
\hline 6 & 43,2 & 43,5 & 0,69 \\
\hline \multicolumn{3}{|c|}{ Rata-rata error (\%) } & 0,49 \\
\hline
\end{tabular}

Berdasarkan pada Tabel 1, tingkat akurasi didapatkan dengan perhitungan sebagai berikut:

$$
\begin{aligned}
& \text { Akurasi }(\%)=100 \%-(\text { rata }- \text { rata error }) \\
& \text { Akurasi }(\%)=100 \%-0,49 \% \\
& \text { Akurasi }(\%)=99,51 \%
\end{aligned}
$$

Tabel 2 Hasil pembacaan sensor suhu dua dan alat kalibrasi suhu

\begin{tabular}{|c|c|c|c|}
\hline No & Thermometer $\left({ }^{\circ} \mathrm{C}\right)$ & $\begin{array}{l}\text { Sensor } \\
\text { Suhu }\left({ }^{\circ} \mathrm{C}\right)\end{array}$ & Error (\%) \\
\hline 1 & 36,7 & 36,75 & 0,14 \\
\hline 2 & 36,7 & 36,75 & 0,14 \\
\hline 3 & 36,5 & 36,5 & 0 \\
\hline 4 & 36,8 & 36,75 & 0,14 \\
\hline 5 & 36,6 & 36,5 & 0,27 \\
\hline 6 & 36,6 & 36,5 & 0,27 \\
\hline \multicolumn{3}{|c|}{ Rata-rata error (\%) } & 0,16 \\
\hline
\end{tabular}

Berdasarkan pada Tabel 2, tingkat akurasi didapatkan dengan perhitungan sebagai berikut:

$$
\begin{aligned}
& \text { Akurasi }(\%)=100 \%-(\text { rata }- \text { rata } \text { error }) \\
& \text { Akurasi }(\%)=100 \%-0,16 \%
\end{aligned}
$$

Akurasi (\%) $=99,84 \%$

\subsection{Pengujian Peringatan Menggunakan Kode Warna Suhu Pada Smartphone}

Tujuan peringatan kode warna, kuning, hijau, dan merah pada tampilan digital suhu di smartphone untuk mempermudah perawat atau dokter mengetahui kondisi pasien dengan maksud warna kuning pada suhu $\left(30.0^{\circ} \mathrm{C}-35.9^{\circ} \mathrm{C}\right)$ maka pasien mengalami Hipotermia, warna hijau $\left(36.0{ }^{\circ} \mathrm{C}-37.9{ }^{\circ} \mathrm{C}\right)$ maka pasien dalam kategori normal dan warna merah (38.0 ${ }^{\circ} \mathrm{C}-43.0{ }^{\circ} \mathrm{C}$ ) maka pasien mengalami demam. Terdapat alarm pada alat jika suhu diatas $37.9^{\circ} \mathrm{C}$.

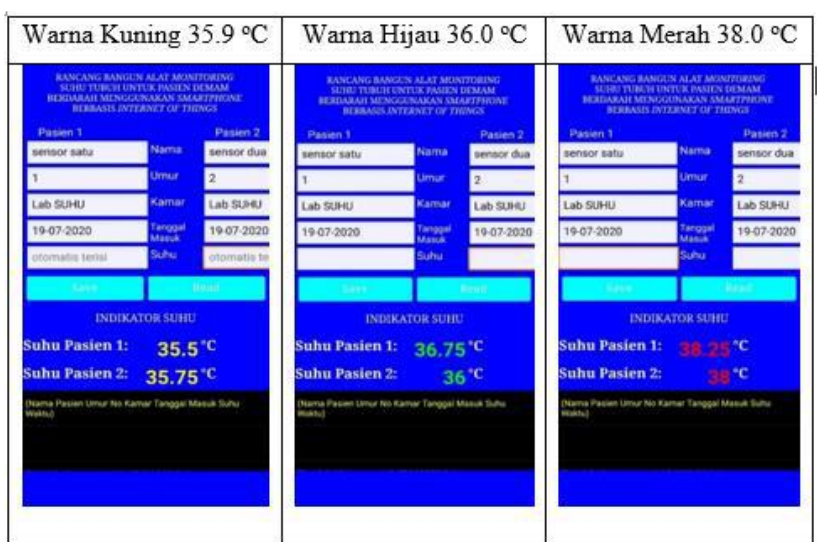

Gambar 5 Hasil pengujian warna kuning, hijau dan merah

\subsection{Pengujian Alarm}

Tujuan dari pengujian alarm adalah untuk mengetahui apakah alarm yang sudah diatur berfungsi dengan benar, alarm akan berbunyi pada alat jika suhu pasien DBD suhunya diatas $37.9^{\circ} \mathrm{C}$.

Tabel 3 Pengujian alarm

\begin{tabular}{|c|c|c|c|}
\hline No & Suhu $\left({ }^{\circ} \mathrm{C}\right)$ & $\begin{array}{l}\text { Kondisi } \\
\text { Buzzer }\end{array}$ & $\begin{array}{l}\text { Tegangan } \\
\text { Keluaran } \\
\text { Relay (volt) }\end{array}$ \\
\hline 1 & 36,0 & Tidak Aktif & 0 \\
\hline 2 & 37,9 & Tidak Aktif & 0 \\
\hline 3 & 38,0 & Aktif & 4,8 \\
\hline 4 & 39,0 & Aktif & 4,8 \\
\hline 5 & 40,0 & Aktif & 4,8 \\
\hline
\end{tabular}

\subsection{Pengujian Keseluruhan Sistem}

Pengujian Sensor suhu pada alat akan diletakan diketiak orang dewasa dengan suhu tubuh normal dan pengukuran secara bersamaan dengan Thermometer. Data didapatkan pada percobaan monitoring dengan rentan waktu 5 menit, 10 menit, 15 menit, 20 menit, 25 menit dan 30 menit. 


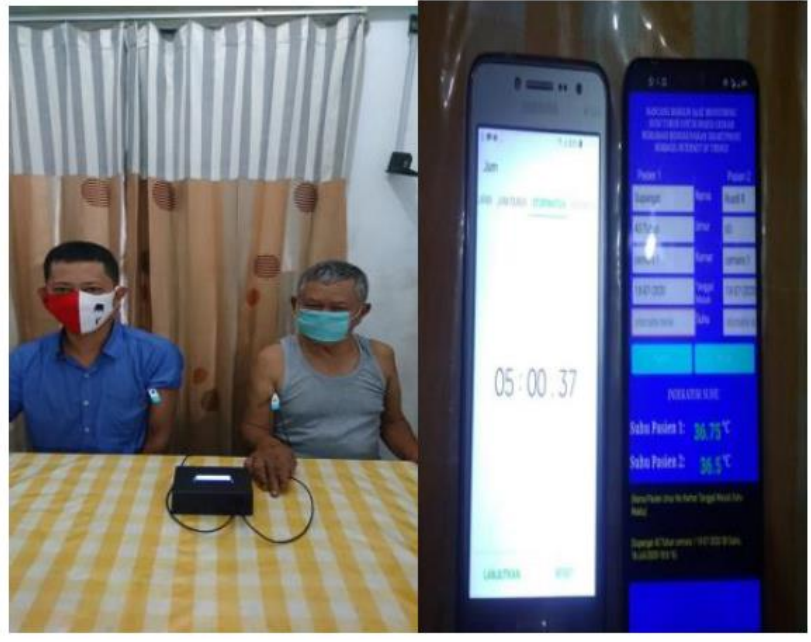

Gambar 6 Pengukuran suhu tubuh pada tubuh orang dewasa

Data pengukuran pasien satu
Nama : Supangat
Umur : 43 Tahun
Tanggal : 18- Juli-2020
Data pengukuran pasien dua

$\begin{array}{ll}\text { Nama } & : \text { Rusdi Raharjo } \\ \text { Umur } & : 60 \text { Tahun } \\ \text { Tanggal } & : \text { 18- Juli-2020 }\end{array}$

Tabel 4 Hasil pengukuran sensor suhu dan termometer pada pasien

\begin{tabular}{|c|c|c|c|c|}
\hline No & $\begin{array}{l}\text { Waktu } \\
(\text { menit })\end{array}$ & $\begin{array}{l}\text { Thermometer } \\
\left({ }^{\circ} \mathrm{C}\right)\end{array}$ & $\begin{array}{l}\text { Sensor } \\
\text { Suhu } \\
\left({ }^{\circ} \mathrm{C}\right)\end{array}$ & $\begin{array}{l}\text { Error } \\
(\%)\end{array}$ \\
\hline 1 & 5 & 36,4 & 36,5 & 0,27 \\
\hline 2 & 10 & 36,5 & 36,75 & 0,68 \\
\hline 3 & 15 & 36,4 & 36,5 & 0,27 \\
\hline 4 & 20 & 36,4 & 36,75 & 0,96 \\
\hline 5 & 25 & 36,6 & 36,75 & 0,41 \\
\hline 6 & 30 & 36,5 & 36,25 & 0,68 \\
\hline & \multicolumn{3}{|c|}{ Rata-rata error $(\%)$} & 0,55 \\
\hline
\end{tabular}

Berdasarkan pada Tabel 3, tingkat akurasi didapatkan dengan perhitungan sebagai berikut:

$$
\begin{aligned}
& \text { Akurasi }(\%)=100 \%-(\text { rata }- \text { rata error }) \\
& \text { Akurasi }(\%)=100 \%-0,55 \% \\
& \text { Akurasi }(\%)=99,45 \%
\end{aligned}
$$

\section{KESIMPULAN}

Proses hasil pembacaan pada smartphone bekerja dengan baik sesuai pembacaan dimodul dan untuk pembacaan di smartphone lebih lama karena mengambil data di database terlebih dahulu kemudian ditampilkan di smartphone. Alat ini dapat digunakan untuk monitoring suhu tubuh secara realtime dari jarak jauh melalui smartphone yang dilengkapi peringatan kode warna, kuning, hijau, merah pada tampilan digital suhunya untuk mengetahui kondisi pasien. Menggunakan dua buah sensor suhu DS18B20 untuk dua orang yang pengukurannya diletakan diketiak pasien. Pada pengujian tingkat akurasi sensor suhu di dapatkan hasil yaitu sensor suhu satu sebesar 99,51\% dan sensor suhu dua sebesar 99,42\%. Pengujian tingkat akurasi ketika sistem tersebut di implementasikan pada orang dewasa yaitu sebesar $99,45 \%$.

\section{REFERENSI}

[1] R. D. Astuti, I. Ismawati, L. H. Siswanti, and A. Suhartini, "Sebaran Vektor Penyakit Demam Berdarah (Aedes aegypti) di Kampus Universitas Islam Bandung," Glob. Med. Heal. Commun., vol. 4, no. 2, p. 82, 2016,

[2] J. Budiarto and S. Hadi, "Sistem Kendali Peralatan Elektronik Rumah Tangga Berbasis Internet Of Things Menggunakan Protokol MQTT," J. Bumigora Inf. Technol., vol. 2, no. 1 , pp. $1-11,2020$

[3] A. Heryanto, J. Budiarto, and S. Hadi, "Sistem Nutrisi Tanaman Hidroponik Berbasis Internet Of Things Menggunakan NodeMCU ESP8266," J. Bumigora Inf. Technol., vol. 2, no. 1, pp. 31-39, 2020

Z. A. Kurnia Sari, H. Permana, and W. Indrasari, "Karakterisasi Sensor Photodioda, Ds18B20, Dan Konduktivitas Pada Rancang Bangun Sistem Deteksi Kekeruhan Dan Jumlah Zat Padat Terlarut Dalam Air," SPEKTRA J. Fis. dan Apl., vol. 2, no. 2, p. 149,2017

F. Supegina and E. J. Setiawan, "Rancang Bangun Iot Temperature Controller Untuk Enclosure Bts Berbasis Microcontroller Wemos Dan Android," J. Teknol. Elektro, Univ. Mercu Buana, vol. 8, no. 2, pp. 145150, 2017. 
[6] Y. Efendi, "Rancangan Aplikasi Game

Edukasi Berbasis Mobile Menggunakan App

Inventor," J. Intra-Tech, vol. 2, no. 1, p. 41, 2018.

[7] A. Shukla, S. Chaturvedi, and Y. Simmhan, "A Review on Internet of Things, Internet of Everything and Internet of Nano Things," Int. J. Comput. Appl. (0975 8887), vol. 113, no.

1, pp. 1-7, 2017

[8] R. K. Kodali and K. S. Mahesh, "A low cost implementation of MQTT using ESP8266," Proc. 2016 2nd Int. Conf. Contemp. Comput. Informatics, IC3I 2016, no. October, pp. 404-408, 2016

[9] D. M. Gumelar, M. Rivai, and T. Tasripan, "Rancang Bangun Wireless Electronic Nose Berbasis Teknologi Internet of Things," $J$. Tek. ITS, vol. 6, no. 2, pp. 6-10, 2017

[10] R. A. Wijaya, S. W. L. W. Lestari, and M. Mardiono, "Rancang Bangun Alat Monitoring Suhu dan Kelembaban Pada Alat Baby Incubator Berbasis Internet Of Things," J. Teknol., vol. 6, no. 1, p. 52, 2019 